\title{
PROCEDURAL JUSTICE IN THE COURTROOM: THE FACTOR STRUCTURE AND PSYCHOMETRIC PROPERTIES OF THE REVISED PROCEDURAL JUSTICE SCALE
}

In Polish psychology there has been no systematic research so far on the experience of contact with courts and on the evaluation of this experience using the theory of procedural justice. Polish psychologists do not have Polish instruments measuring procedural justice at their disposal. The Procedural Justice Scale is a measure operationalizing the dimensions of procedural justice according to Tyler's model: respect, neutrality, voice, understanding, and influence. The aim of the present article is to present the work on the revised version of the Procedural Justice Scale, measuring procedural justice operationalized exclusively in psychological terms, and to present the psychometric properties of this scale. In particular, the author tested the reliability of the instrument and verified its validity based on confirmatory factor analysis, scale intercorrelations, and intergroup differences. The results confirmed the five-factor structure of procedural justice. They also confirmed the criterion validity of the measure, reflected in correlations with validation instruments.

Keywords: procedural justice; the judiciary; district courts; civil cases; Procedural Justice Scale.

Correspondence concerning this article should be addressed to TOMASZ PRUSIŃSKI, Institute of Psychology, Department of Personality Psychology, Maria Grzegorzewska University in Warsaw, ul. Szczęśliwicka 40, 02-353 Warsaw, Poland; email: tomasz.prusinski@op.pl; ORCID: https://orcid.org/0000-0002-8782-1498.

The research results presented in this article come from research project BSTP 29/18-I, financed by the Polish Ministry of Science and Higher Education. The study was approved by the Research Ethics Board (approval decision no. 158-2017/2018). Prior to conducting the study, the author obtained permission from the presidents of district courts. The author wishes to thank the presidents of district courts for their permission to conduct empirical research. The study was conducted with significant support from the Court Watch Poland Foundation, based in Torun. The author extends his gratitude to President of the Foundation, Bartosz Pilitowski, for the support received while conducting empirical research, and to Stanisław Burdziej for making his Procedural Justice Scale available and for expert consultation in the process of instrument revision. 


\section{INTRODUCTION}

Institutional justice issues occupy an important place in the psychological literature, particularly internationally (Thibaut \& Walker, 1975; Lind \& Tyler, 1988; Vermunt et al., 1993; Tyler \& Huo, 2002; Tomkins \& Applequist, 2008; Törnblom \& Vermunt, 2016), and more recently also in the Polish literature (Daniel, 2007; Niesiobędzka, 2009; Skąpska \& Bryda, 2013; Guzik et al., 2018; Prusiński, 2018). Various ideas and scales for measuring institutional justice have been conceptualized by researchers investigating these issues.

Institutional justice is defined in the context of the individual's functioning in a social institution, with emphasis placed on the fact that it is subjective evaluation accompanied by a feeling about the extent to which his or her individual expectations regarding the external institutional entity have been satisfied and the extent to which the consequences of this contact can be considered fair (Lind \& Tyler, 1988). The evaluation process is continual; it also involves the monitoring of the balance between the profits obtained in the course of institutional redistribution and the burdens imposed if responsibility for burdens is divided. Individuals not always evaluate this reallocation as fair (Bierhoff et al., 1986). A significant contribution to the development of a theory concerning institutional justice was made by Colquitt, who while reporting his research findings stressed that institutional justice explained the exceptional variance in socially significant human behaviors, such as institutional engagement, trust in leadership, or civic behaviors (Colquitt et al., 2001).

The term "institutional justice" was introduced into the social and legal sciences in the mid-1970s by Thibaut and Walker (1975). The first studies addressing these issues presented institutional justice as comprising two dimensions: procedural and distributive justice. Adams' (1963) research on inequity, prior to that of Thibaut and Walker, was focused mainly on the distributive justice dimension. The author pointed out that the evaluation of fairness concerned, above all, the individual's share in the distributed resources and burdens. Thus, the focus was on the fact that the evaluation is, in a way, a summary of the final state, which means that the process was reduced to the fairness of its outcome.

In the early 1980s, a series of studies and the resulting theoretical reflection drew attention to the fact that the manner in which a decision is arrived at is more important than the decision itself (Lind \& Tyler, 1988). Greenberg's (1986) research on institutional honesty and the analysis he performed also yielded a two-component solution, revealing a procedural factor distinct from the distributive factor. It was argued that decision evaluation was not so significant or, 
at any rate, that it was not the only evaluation. Individuals also evaluate the way in which the decision is made (Tyler, 2007; 2010).

Burdziej (2018) points out that viewing institutional justice in terms of procedural justice or process justice has been an increasingly influential approach at present. At the same time, he notes that philosophical and legal perspectives still dominate in Polish-language publications. The psychological perspectivewhich is the most interesting one for the social sciences, including psychologywas only marginally developed until recently. The tradition of legal sciences identifies procedural justice with code guarantees and legal regulations. It is pointed out that a justly made decision is an action performed in accordance with the letter of the law. The psychological perspective emphasizes that evaluations are made by individuals and that, consequently, the estimation has a subjective character, orienting the individual's feelings, thoughts, and behaviors.

\section{PROCEDURAL JUSTICE IN THE COURTROOM}

One of the main scholars exploring justice in accordance with both approaches outlined above is Tyler (2007), who usually works as a member of research teams (Tyler, 1984; Lind \& Tyler, 1988; Tyler \& Huo, 2002; Murphy et al., 2009). His studies address this issue in various institutional contexts. Tyler investigates procedural justice from the perspective of a person taking part in institutional processes whose outcome is a particular decision or ruling and over which the individual does not have full control: otherwise evaluating the fairness of the procedure or its outcome would not make sense. Among the institutions he examined is the judiciary. It is the measurement of procedural justice exclusively in the context of the judiciary that the present empirical study is devoted to.

According to Tyler (2007), procedural justice is considered in a special way there and differs from justice as considered in the context of other social institutions because the individual's satisfaction is not the main goal-at any rate, not for the court. The goal is just resolution of conflicts as well as accurate and appropriate administration of the law. Tyler stresses, however, that courts also have to treat citizens seriously, because if the goal is to resolve a conflict, then the fact that people take the court's decision seriously and accept it does make a difference. What is more, whether people believe that justice has been achieved is crucial to their trust in the judicial system.

In the case of the judiciary, procedural justice refers to the fairness of the trial, though not only. Individuals evaluate the fairness of the decision-making pro- 
cess, the judicial decision, or the sentence. Procedural justice is defined as the evaluation of the optimality of the way in which the decision has been made. Together with a group of collaborators, Tyler performed extensive empirical and theoretical analyses of procedural justice, whose aim was also to distinguish the aspects of evaluation that could constitute the dimensions of procedural justice.

Tyler's $(1984,2007,2010)$ classical model of procedural justice comprises four dimensions: voice, respect, neutrality, and understanding. Procedural justice manifests itself in the fact that the person whose case is decided in court has been treated with attention and respect and feels that they have been given sufficient opportunity to present their position, that the language in the courtroom is clear and comprehensible and so is the content of the decision, and that the decisionmaking body has been fair and neutral.

Sometimes trust is added as a dimension. It seems to be complex and partly related, for instance, to the decision maker's neutrality. The feeling that the decision-making process is fair and that the decision maker maintains impartiality, as well as other courtroom experiences, results in a feeling that the judge is trustworthy. Occasionally, a dimension referred to as friendliness is also mentioned (Burdziej, 2018; Tyler, 2007). It is understood as a feeling that the decisionmaker shows interest in the needs of the individual whose case they are to decide.

In the above context, a study worth mentioning is the one by Cattaneo and Goodman (2010), which equate procedural justice with a sense of empowerment in the courtroom. The researchers point out that leaving the courtroom with an unshaken sense that the proceedings have been fair results in a relatively stable belief that one's expectations are understood, that these expectations can potentially be met, and that they will be reflected in the judge's decision and words throughout the court proceedings.

As stated above, the leading models distributing the phenomenon of procedural justice have been developed by Tyler and colleagues. In these models it is stressed that the mechanism of experiencing procedural justice anchors a more fundamental process: building a sense of identity (Tyler et al., 1996; Blader \& Tyler, 2003). A sense of experiencing various aspects of justice is one of the main building blocks of a person's social identity because it enables them to infer their significance in the social group. The experience of fair treatment is a sign of recognition and status, and these in turn determine the individual's identity. Dickerson and Kemeny (2004) stress that procedural justice is the element of social life that a person is almost automatically sensitive to, because it is the basis of social evaluation and allows him or her to maintain the social self. 
It can also be concluded from the above that the degree of one's identification with a particular institution may determine the significance they attach to being fairly treated by that institution. This association works on a feedback basis: the more frequent the individual's experience of institutional fairness, the stronger the need for identification with the institution (Burdziej, 2018).

The judiciary is an important public institution since-despite being treated differently depending on the person's role in the proceedings - at various stages of human life it becomes a resource that serves the purpose of organizing the individual's functioning and supporting them in the process of coping with life difficulties and limitations (Antonovsky, 2005; Prusiński, 2018).

Court proceedings, in which a person can manifest their expectations (which, after all, define the scope of the individual's personal helplessness, lack of resources, and lack of coping skills) to an external decision-making body, is a space where one can experience enhancement or stress. The latter appears when the person feels that they have been given dismissive or disrespectful treatment. The experience of procedural justice is a resource enhancing the elimination of imbalance. The way one is treated and the way the decision is made supports the regeneration of mental strength because people believe that an unjust decision leads to unjust results.

It should also be noted that the justice research conducted in recent years points to its links with well-being, understood in accordance with two orientations rooted in different philosophical traditions (hedonistic and eudaimonic). Calton and Cattaneo (2014) directly show that a high level of well-being is related to the aggregate experience of procedural justice in the dynamic process of receiving institutional support. Diener et al. (2003) support this claim, underscoring that people's positive experiences in various domains of social life are key factors that add value to their life, even to a considerable degree. In the present study this was assumed - since we have no other measures that would operationalize procedural justice adapted to the Polish conditions (this will be discussed at some length in the next section) - demonstrating that the score on the validated Procedural Justice Scale (PJS) is significantly positively related to scores on the scales measuring well-being will constitute evidence of the measurement value of the PJS. 


\section{PROCEDURAL JUSTICE MEASUREMENT: THE AIM OF THE PRESENT STUDY}

So far there has been little research on the experience of contact with courts and on the evaluation of this experience using the theory of procedural justice. Institutional justice research does not have a particularly long tradition in Polish psychology: little empirical material is currently available (Prusiński, 2018). Just like in other countries of Central and Eastern Europe, the few existing studies have been carried outby sociologists and economists rather than psychologists (Boda \& Medve-Balint, 2014; Burdziej, 2018; Burdziej et al., 2018; Cohn et al., 2000). The sociology of law in particular has quite a long record of research devoted to the judicial system (Podgórecki, 1971; Kurczewski, 1982; Kurczewski \& Fuszara, 2004). Although measures of procedural justice have been available worldwide for decades, psychologists in Poland do not have their Polish adaptations at their disposal. As pointed out above, the issue seems to be important and requires exploration also in the Polish context. The perspective of the social sciences is only marginally present in the understanding of procedural justice.

It should be noted, however, that although there are numerous measures of procedural justice, in the context of a lawsuit that an individual takes place in justice has been measured by means of a few of them. The main objection here is that these measures seem to be created exclusively for the needs of the current empirical studies and only provisionally validated (Calton \& Cattaneo, 2014). Some instruments are developed to measure justice exclusively in strictly defined trial settings and include open-ended questions (Ptacek, 1999). They concern criminal cases, and their items describe the circumstances of the experience of justice, for examples, by victims of violence. Some researchers admit that measurement standards for procedural justice in the courtroom are lacking (Calton \& Cattaneo, 2014; Cattaneo \& Goodman, 2010). In such context it is difficult, if not impossible, to avoid making comparisons. The measures available in Poland (Jałoszewski, 2012) are focused on organizational and infrastructural issues - on those aspects of the satisfaction of participants in judicial proceedings that have little to do with the definition of procedural justice as presented in this article.

As has been mentioned, Tyler's (2007) model, which provides the basis for the operationalization of procedural justice, has been developed for decades (Tyler \& Rasinski, 1991) and appears to be a model that yields the broadest description of an individual's experiences in the courtroom that may serve as the basis for their general appraisal of procedural justice. The measure based on Tyler (2007) can be used in judicial proceedings in diverse contexts, for example in civil cases. 
The first Polish-language version of the PJS (Blader \& Tyler, 2003; 2009), operationalizing procedural justice mainly in accordance with Tyler's model, was developed by Burdziej with a collaborating team (Burdziej, 2018; Burdziej et al., 2018). The development work took several years, and its results are highly valuable. Still, if the measure is to be used by a psychologist, it requires a few major improvements. When revising the scale, the authors focused not only on the subjective experience of participants in court proceedings. The first Polish-language version of the scale goes beyond behaviors identifiable with the measured construct and includes items operationalizing formal issues, especially organizational and infrastructural ones. However, the results of research on institutional justice show that the factors determining the evaluation of the courtroom experience are the sense of influence on the course of the proceedings and the attitude of the judge. The construct thus presented is a concept that requires separate operationalization (Hornowska, 2006).

Importantly, the results of factor analyses show that Burdziej's (2018) the 16-item scale differs slightly from the four-component conceptualization proposed by Tyler and colleagues. The internal structure of the Procedural Justice Scale comprises five dimensions. Apart from voice, understanding, neutrality, and respect, a clearly distinct factor is the sense of influence on court proceedings and on the judge's decision.

The measure also includes questions about other aspects of participation in court proceedings, such as: the duration of the pending lawsuit, the participant's previous conviction record, and the treatment by the security guards or by the police. Most items follow a closed format, but there are some in which the respondent's task is to give an unguided answer. The lack of uniformity manifests itself also in the fact that the questionnaire contains both items with gaps to be filled and items with multiple options to choose from. The authors of the PJS operationalized some aspects of the concept of procedural justice with a small number of items (Burdziej, 2018). It seems that, especially in the construction of psychological scales, introducing one or two items into the measure is insufficient to cover an area of behavior that is an indicator of an attribute of interest. Moreover, it seems that, at present, assessing reliability by means of the internal consistency method, which has recently been severely criticized (Aranowska \& Rytel, 2013), is insufficient too, though indispensable. Further examination of these issues will only make the measure more valuable.

The aim of the present study was to revise the Polish version of the Procedural Justice Scale in accordance with the comments made above, in such a way as to prepare a separate instrument for measuring procedural justice operational- 
ized exclusively in psychological terms, and to determine the psychometric parameters of the revised Polish version of the PJS.

Another important aim was to check if the five-factor structure of the construct would be reproduced and to what extent a psychometric assessment made it legitimate to leave the model proposed by Burdziej and his team unchanged. In particular, the aim was to test the reliability of the instrument and to verify its validity based on confirmatory factor analysis, subscale intercorrelations, and intergroup differences.

\section{METHOD}

\section{Participants and procedure}

The data used to analyze the basic parameters measured by the revised PJS were obtained in research conducted in civil departments of Polish district courts. The study involved plaintiffs and defendants in in civil proceedings. The measurements were performed after a court sitting. In most cases $(69.6 \%)$ this took place during the trial: the judge did not resolve the case and did not announce the decision at that particular sitting. Thus, the measurement procedure took place at the time when the participant had just experienced a court sitting during which his or her basic interaction with the judge enabled them to evaluate the fairness of the trial and honesty of the judge's work as well as experiencing the courtroom reality in the Polish judicial system. The descriptive statistics and demographic data for the study sample are presented in Table 1. The participants were 115 individuals aged between 20 and $75(M=43.94, S D=15.13)$. The study began in July and lasted until November 2018.

Participation in the study was voluntary. The participants were informed about the purpose and asked to give their consent to take part in it. Then, they completed the Procedural Justice Scale. After that, they were asked to complete two questionnaires measuring well-being (Ryff, 1989) and satisfaction with life (Pavot, et al., 1998). Additionally, they filled in respondent's data surveys regarding their standard sociodemographic data. The subjects received no remuneration for their participation. The research was conducted after the presidents of district courts had granted their permission. It was conducted by trained observers of court sittings, who had previous experience of research in Polish courts. The observers were not individuals with a thorough background in law or psychology, but their earlier work made it legitimate to assume that they had sufficient 
knowledge about the organizational structure of the Polish judicial system, the main procedural rules, and the courtroom terminology.

Table 1. Participants' Demographic Characteristics

\begin{tabular}{|c|c|c|}
\hline Variable & $\%$ & $\mathrm{n}$ \\
\hline \multicolumn{3}{|l|}{ Gender } \\
\hline Women & 54.8 & 63 \\
\hline Men & 45.2 & 52 \\
\hline \multicolumn{3}{|l|}{ Education } \\
\hline Elementary & 8.8 & 10 \\
\hline Basic vocational & 14.8 & 17 \\
\hline Secondary & 34.7 & 40 \\
\hline Higher & 41.7 & 48 \\
\hline \multicolumn{3}{|l|}{ Place of residence } \\
\hline Village & 27 & 31 \\
\hline Town below 20,000 & 6.1 & 7 \\
\hline Town from 20,000 to 100,000 & 19.1 & 22 \\
\hline City above 100,000 & 47.8 & 55 \\
\hline \multicolumn{3}{|l|}{ Role in court proceedings } \\
\hline Plaintiff & 62.6 & 72 \\
\hline Defendant & 37.4 & 43 \\
\hline \multicolumn{3}{|l|}{ Which time in court } \\
\hline First & 40.9 & 47 \\
\hline Second to fourth & 50.4 & 58 \\
\hline Fifth or subsequent & 8.7 & 10 \\
\hline
\end{tabular}

\section{MEASURES}

The Procedural Justice Scale (PJS). The revised version tested in the present study consists of 22 items; seven of them are reverse-coded and the remaining ones are positively keyed. The PJS is a self-report measure with a 5-point Likert scale from 1 (strongly disagree) to 5 (strongly agree). Subscale scores are computed as the mean of scores for all items making up a given subscale. It is also possible to compute the overall score. All PJS items are provided in Appendix 1 of the present article.

As noted above (p. 88), the study was preceded by a revision of the PJS. Items concerning formal lawsuit issues were removed from the current version of the scale, adapted by Burdziej (2018). The removed questions included those about the duration of the lawsuit, the frequency of visits to the court, and about who asked the witnesses questions. Open-ended questions were removed, for 
instance the one about which aspects of the court's work made the best impression on the party in proceedings. The stimulus format and the response scale were made uniform.

Due to the small number of items operationalizing the key dimensions of procedural justice in the PJS, six additional items were introduced in order to balance the number of items in some of the subscales. This was the case with the Neutrality and Understanding subscales. The items added to the PJS, the final version of which is presented in Appendix 1, were marked with an asterisk. The authors of the PJS were consulted about this.

The Temporal Satisfaction With Life Scale (TSWLS). The instrument that was used is the Polish version of the scale developed by Pavot, Diener, and Suh (1998; adapted by Cieciuch \& Karaś, 2017). The scale measures integrated an evaluation of the quality of life as a whole that was, is, and will continue. It is a self-report measure, in which the subjects give their answers on a 7-point scale from completely disagree to completely agree. Internal consistency (Cronbach's $\alpha$ ) was .92 for the overall score.

The Psychological Well-Being Scale (PWBS). This instrument was developed by Ryff (1989) and adapted for Polish by Cieciuch and Karaś (2017). It measures integrated psychological well-being understood in eudaimonic terms. The questionnaire is a self-report measure; participants give their answers on a 6-point scale, from strongly disagree to strongly agree. The reliability of the scale is very high, reaching .86 for the overall score.

\section{RESULTS}

\section{The Reliability and Basic Distribution Parameters of PJS Scores}

The reliability of each subscale and the PJS as a whole was assessed by means of several coefficients: Cronbach's $\alpha$ internal consistency coefficient, Jöreskog's composite reliability (CR) coefficient, Aranowska's $\gamma$ coefficient, and Q2 intra-class correlation coefficient. Intraclass coefficients were computed in a two-factor model (type: consistency). The results are presented in Table 2. Descriptive statistics (mean scores, standard deviations, skewness, and kurtosis) are provided in Table 3. Based on the values of skewness and kurtosis, it can be concluded that the distribution of procedural justice is close to normal: for each scale and for the overall PJS score these values range between -1 and 1 .

In the case of information about the reliability of the measure, what is important is not only to answer the question of whether and how accurately the 
observed results reflect the corresponding actual results, but also to establish how exactly the observed results allow researchers to generalize about a person's behavior in a specific class of situations - in this case, situations involving procedural justice issues. Considering the increasing popularity of the generalizability coefficient (Aranowska, 2005; Aranowska, Rytel, 2013), @2 values are shown in Table 2; it should be noted that $\varrho_{2}$ is always lower than Cronbach's $\alpha$. This will enable broader comparisons of the reliability of PJS subscales with the corresponding values for other subscales of different measures.

Table 2. Reliability Coefficients for PJS Subscales and Overall Score

\begin{tabular}{lllll}
\hline \multicolumn{1}{c}{ Scale } & $\alpha$ & $C R$ & $\gamma$ & $\mathrm{Q}_{2}$ \\
\hline Voice & .83 & .91 & .71 & .41 \\
Neutrality (impartiality) & .71 & .84 & .65 & .45 \\
Influence & .25 & .44 & .32 & .14 \\
Respect & .66 & .82 & .59 & .25 \\
Understanding & .48 & .60 & .40 & .19 \\
Overall score & .89 & .98 & .86 & .28 \\
\hline
\end{tabular}

Note. $\alpha$-Cronbach's internal consistency coefficient, $C R$-Jöreskog's composite reliability coefficient, $\gamma$-Aranowska's reliability coefficient, $\varrho_{2}$-intra-class correlation coefficient.

The above coefficients reveal that the estimated reliability is high for the overall score and acceptable for three of the five analyzed subscales. Measurement reliability for the Voice, Neutrality, and Respect subscales ranges from moderate to high. One ought to be very cautious when interpreting and analyzing the remaining two dimensions of procedural justice-Influence and Understanding - on the basis of PJS scores. For demonstrative purposes and with a view to future studies devoted to specific dimensions of procedural justice, these scales were included in further analyses.

Table 3. Basic Parameters of PJS Score Distributions

\begin{tabular}{lcccc}
\hline \multicolumn{1}{c}{ Scale } & $M$ & $S D$ & \multicolumn{1}{c}{$S$} & \multicolumn{1}{c}{$K$} \\
\hline Voice & 26.65 & 5.18 & -0.37 & -0.33 \\
Neutrality (impartiality) & 11.63 & 2.51 & -0.36 & -0.52 \\
Influence & 6.07 & 1.74 & -0.03 & -0.03 \\
Respect & 21.54 & 4.26 & -0.42 & 0.23 \\
Understanding & 14.26 & 2.85 & -0.06 & -0.60 \\
Overall score & 80.15 & 13.54 & -0.33 & -0.01 \\
\hline
\end{tabular}

Note. $M$-mean, $S D$ —standard deviation, $S$-skewness, $K$ - kurtosis. 


\section{The Factor Structure of Procedural Justice}

A confirmatory factor analysis (CFA) was performed to assess the structure of procedural justice as conceptualized by Tyler and measured with the revised Procedural Justice Scale. The model whose fit was tested comprised five latent factors: voice, neutrality, influence, respect, and understanding as well as the procedural justice metavariable. The structural model with the latent variables and their measurement model is graphically illustrated in Figure 1. The figure shows the relations between latent variables and the corresponding observable variables.

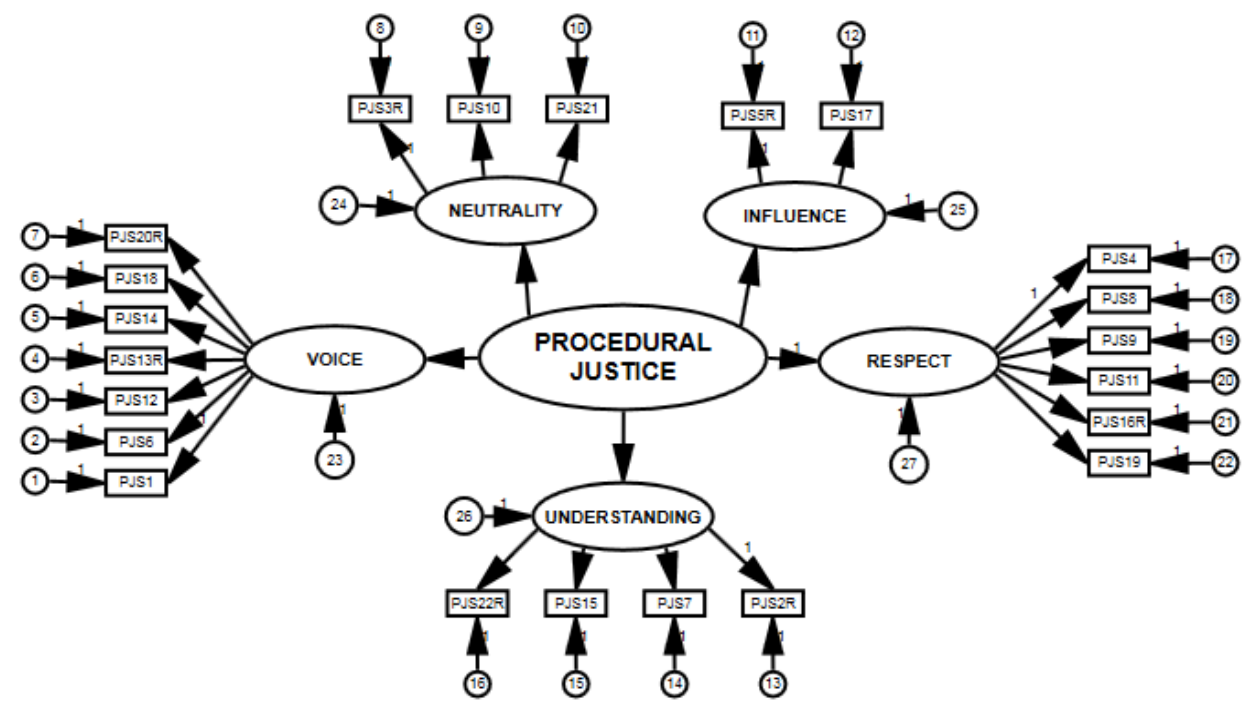

Figure 1. Confirmatory Factor Analysis (CFA)

Note. The diagram includes a model with five latent variables: voice, neutrality, influence, respect, and understanding, their measurement model, and the procedural justice metavariable. The observable variables (partial indicators) operationalizing the latent variables are indicated with abbreviations referring to PJS items.

The value of the most important model fit estimator, root mean square error of approximation (RMSEA), is .053; the bounds of its $90 \%$ confidence interval are $[.034, .070]$. Their value is below .08 , which has been commonly adopted as a criterion (Szymańska, 2016). This attests to the good fit of the model (Konarski, 2016). The values of most fit indices for the PJS are either good or acceptable. The obtained ratio of $\chi^{2}$ and the number of degrees of freedom 
$\left(\chi^{2} / \mathrm{df}=1.32, p<.01\right)$ does not exceed 2.5 and even meets the more restrictive criterion, recommending the rejection of models for which this ratio exceeds 2 . Only the comparative fit index $(\mathrm{CFI}=.78)$ reached a value slightly below the threshold suggested in the literature (Konarski, 2016).

The confirmatory factor analysis was meant to show if the theoretically established dimensions indeed underlie the subscales made up of partial indicators and to what extent the factor structure obtained for the Polish sample is comparable to the structure of the original measure, which would confirm the factorial validity of the Polish version of the PJS. The proposed model with five latent factors proved to have a good fit.

\section{Intercorrelations of PJS Subscales}

What yielded important information about the validity of the PJS was the test of intercorrelations between its subscales. In view of the theoretical assumption of the model (Burdziej, 2018; Tyler, 1984, 2010) that procedural justice is a construct made up of interrelated dimensions, it was expected that the subscales measuring different aspects of procedural justice would be positively interrelated. Because they load on the overall score, their correlations with this score should also be high. Table 4 presents Pearson's $r$ and Spearman's rho coefficients between PJS subscales and the overall score.

Table 4. Intercorrelations of PJS Subscale and Overall Scores

\begin{tabular}{|c|c|c|c|c|c|}
\hline & Voice & Understanding & Neutrality & Respect & Influence \\
\hline Voice & & .426 & .766 & .710 & .542 \\
\hline Understanding & & & .337 & .437 & .346 \\
\hline Neutrality & & & & .722 & .449 \\
\hline Respect & & & & & .426 \\
\hline $\begin{array}{l}\text { Influence } \\
\text { Overall score }\end{array}$ & .918 & .631 & .831 & .860 & .635 \\
\hline
\end{tabular}

Note. All correlation coefficients are significant at the level of at least .01.

The correlations obtained in the study confirmed our expectations. The analysis of the matrix of intercorrelations between the PJS subscales shows that, as predicted, the subscales were significantly correlated with one another, and that the directions of these correlations were predictable. Some scales are very strongly intercorrelated: Voice and Neutrality, Voice and Respect, and Neutrality 
and Respect. Most correlations were moderate. The analysis revealed high and significant correlations between the subscales measuring the components of procedural justice and the overall PJS score. Their values make it legitimate to conclude that there is an essential correlation - in this case, positive-between procedural justice as measured by the scale and its dimensions.

The correlations confirm the validity of PJS subcales. The dimensions of procedural justice are interrelated with one another.

\section{Criterion Validity of the PJS}

To analyze the criterion validity of the PJS, an analysis of correlations between PJS scores and validation measure scores was performed.

As noted in the theoretical section, in Poland there are no psychological instruments operationalizing institutional justice, so we chose instruments measuring other variables, which (based on previous empirical research reports and theoretical findings)can be expected to be significantly related to the investigated construct (Prusiński, 2018; Rousseau et al., 2009). The importance of the procedural justice factor for well-being is emphasized.

According to Czapiński (2004), the main predictors of well-being are not material factors, which, at most, foster a particular perception of satisfaction with life. What is more important for perceived well-being than the resources gained (the distributive effect) is the way in which they have been gained (the procedural effect). Adams's (1965) theory of justice postulates that the perception of inequity induces tensions. According to Thibaut and Walker (1975), long-term perception of the lack of justice brings a sense of having no control over personal life and its predictability. Calton and Cattaneo (2014) directly show that a high level of well-being is a function of the aggregate experience of procedural justice associated with receiving institutional support.

Therefore, the data used in the analyses was collected by means of the Temporal Satisfaction With Life Scale (Pavot et al., 1998) and the Psychological Well-Being Scale (Ryff, 1989). Table 5 presents the correlations of the PJS scores with scores on the above measures. 
Table 5. Correlations of PJS Subscale and Overall Scores With Validation Instruments

\begin{tabular}{lcccc}
\hline & TSWLS & $p$ & PWBS & $p$ \\
\hline Voice & .319 & .001 & .379 & .001 \\
Understanding & .102 & .03 & .076 & .04 \\
Neutrality & .255 & .006 & .364 & .001 \\
Respect & .263 & .004 & .295 & .001 \\
Influence & .125 & .02 & .144 & .12 \\
Procedural justice (overall score) & .295 & .001 & .350 & .001 \\
\hline
\end{tabular}

Note. TSWLS-Temporal Satisfaction With Life Scale (overall score) and PWBS-Psychological Well-Being Scale (overall score).

The PJS scores were significantly correlated with the validation measures. The direction of these relationships confirms the link between perceived justice in the courtroom and well-being, understood in accordance with both the eudaimonic paradigm and the hedonistic one. These results are consistent with the expectations and confirm the criterion validity of the PJS. Low correlations (one insignificant: Influence-PWBS $=.144, p=.12$ ) were found for two PJS subscales: Understanding and Influence, which confirms the earlier findings, according to which these dimensions require better fitted operationalizations; further validation efforts must therefore be preceded by reconstructions of these subscales. What is important, the overall PJS score correlates moderately or strongly with scores on all two validation measures.

\section{INTERGROUP DIFFERENCES: PJS SUBSCALES AND DEMOGRAPHIC VARIABLES}

\section{Results According to Gender}

Although researchers argue that the social expectation of procedural justice is universal and that this type of justice is expected to an equal degree by people who vary in terms of education level, age, or income (Tyler \& Lind, 1988), empirical data from the Polish study by Burdziej (2018) lead to different analysis results. A significant variable is gender: men tend to judge procedural justice more critically than women do. Table 6 presents women's and men's PJS scores. 
Table 6. PJS Subscale and Overall Scores for Women and Men

\begin{tabular}{|c|c|c|c|c|c|c|}
\hline & \multicolumn{2}{|c|}{ Women $(n=63)$} & \multicolumn{2}{|c|}{ Men $(n=52)$} & \multirow[b]{2}{*}{$t$} & \multirow[b]{2}{*}{$p$} \\
\hline & $M$ & $S D$ & $M$ & $S D$ & & \\
\hline Voice & 26.68 & 5.45 & 26.62 & 4.90 & 0.067 & .472 \\
\hline Understanding & 14.56 & 2.76 & 13.90 & 2.95 & 0.652 & .112 \\
\hline Neutrality & 11.76 & 2.33 & 11.46 & 2.73 & 0.300 & .263 \\
\hline Respect & 21.60 & 4.62 & 21.46 & 3.83 & 0.142 & .43 \\
\hline Influence & 6.27 & 1.96 & 5.83 & 1.41 & 0.443 & .08 \\
\hline Procedural justice & 80.87 & 14.42 & 79.27 & 12.47 & 1.604 & .265 \\
\hline
\end{tabular}

The reported difference test results indicate that gender does not differentiate the overall level of procedural justice. Differences have not been observed in scores on any of the five subscales, either. Although Polish empirical data show that men score higher than women on the PJS, the results of the present study do not confirm these findings. It can therefore be said that the lack of gender differences confirms Tyler's finding that the expectation of procedural effect is universal. This result may indicate that the measured procedural justice variable is close to the model based on Tyler's conceptualization.

\section{Results According to Age and Education Level}

Burdziej's (2018) research includes an analysis of correlations between procedural justice and control variables, such as age or education. The analyses show that there is no correlation between age and procedural justice; the same goes for the education variable. Tables 7 and 8 present differences associated with age and education.

Table 7. PJS Subscale and Overall Scores in Samples of Young Adults and Adults

\begin{tabular}{|c|c|c|c|c|c|c|c|}
\hline & \multicolumn{2}{|c|}{$\begin{array}{c}\text { Age: } 20 \text { to } 40 \\
(n=46)\end{array}$} & \multicolumn{2}{|c|}{$\begin{array}{l}\text { Age: } 41 \text { to } 75 \\
\quad(n=69)\end{array}$} & \multirow{2}{*}{$t$} & \multirow{2}{*}{$U$} & \multirow[t]{2}{*}{$p$} \\
\hline & $M$ & $S D$ & $M$ & $S D$ & & & \\
\hline Voice & 27.91 & 4.03 & 25.81 & 5.7 & & 1245.00 & .05 \\
\hline Understanding & 14.74 & 2.54 & 13.94 & 3.02 & 1.475 & & .143 \\
\hline Neutrality & 12.00 & 2.32 & 11.38 & 2.62 & & 1406.50 & .298 \\
\hline Respect & 22.00 & 3.55 & 21.23 & 4.67 & 0.947 & & .346 \\
\hline Influence & 6.33 & 1.56 & 5.90 & 1.84 & & 1381.00 & .231 \\
\hline Procedural & 82.98 & 10.80 & 78.26 & 14.86 & 1.969 & & .071 \\
\hline
\end{tabular}

Note. $t$ stands for Student's $t$-test and $U$ for Mann-Whitney $U$ test. 
Table 8. PJS Subscale and Overall Scores for Persons With Secondary and Higher Education

\begin{tabular}{|c|c|c|c|c|c|c|c|}
\hline & \multicolumn{2}{|c|}{$\begin{array}{l}\text { Secondary education } \\
\quad(n=50)\end{array}$} & \multicolumn{2}{|c|}{$\begin{array}{l}\text { Higher education } \\
\quad(n=38)\end{array}$} & \multirow[t]{2}{*}{$t$} & \multirow[t]{2}{*}{$U$} & \multirow[t]{2}{*}{$p$} \\
\hline & $M$ & $S D$ & $M$ & $S D$ & & & \\
\hline Voice & 26.46 & 4.18 & 27.66 & 5.76 & & 780.00 & .151 \\
\hline Understanding & 14.20 & 2.58 & 14.76 & 3.18 & & 847.50 & .384 \\
\hline Neutrality & 11.58 & 2.36 & 11.74 & 2.53 & & 900.50 & .673 \\
\hline Respect & 21.80 & 3.69 & 21.55 & 4.89 & & 910.00 & .735 \\
\hline Influence & 6.10 & 1.47 & 6.18 & 2.20 & & 907.00 & .713 \\
\hline Procedural justice & 80.14 & 10.95 & 81.89 & 16.14 & 0.577 & & .566 \\
\hline
\end{tabular}

Note. $t$ stands for Student's $t$-test and $U$ for Mann-Whitney $U$ test.

Research conducted by means of the PJS revealed no significant differences in scores between young adults and adults. Education did not differentiate perceived procedural justice, either. As regards the education variable, there were no significant differences in PJS scores (i.e., in the overall score or in the subscale scores) between the compared groups of people with secondary and higher education.

In summary, it can be said that age and education turned out not to be significant variables for procedural justice, no differences found. The results confirm the validity of the predictions that the expectation of procedural justice is independent of the education level or age of those who come to court. Age and education do not differentiate the subjective evaluation of the degree to which individual expectations regarding an external institutional entity have been satisfied and the degree to which the consequences of this encounter can be considered fair.

\section{DISCUSSION}

The main aim of the study was to present the psychometric parameters of the revised Polish version of the questionnaire measuring five dimensions of procedural justice: voice, understanding, neutrality, respect, and influence. Another aim was to verify the structure of procedural justice because previous results pointed to a model somewhat different from the four-factor model suggested by Tyler (Burdziej, 2018). It was therefore tested whether and to what extent Tyler's four-component structure of procedural justice was reproduced and to what 
extent psychometric assessment made it legitimate to leave the model proposed by Burdziej and his team unchanged.

The adopted validation strategy yielded the expected results, showing acceptable goodness of measurement. In the Polish population, the study yielded a PJS factor structure close to the results obtained by Burdziej (2018). The results of confirmatory factor analysis confirmed the five-factor structure of procedural justice found by the Polish research team.

The structure of procedural justice is complex and cannot be reduced to a potentially simpler pattern. The reproduction of the dimensions of Tyler's model attests to the high correspondence between the results of CFA analyses and the Tylerian model of procedural justice. It therefore seems that the proposed model should be treated as more than merely an empirical descriptive model.

The above is also related to the stability of the proposed structural model. Further empirical studies will undoubtedly cast new light on this issue. Nevertheless, it should be noted even now that the present empirical study of a Polish population confirmed the stability of the factor structure of procedural justice. It therefore seems more and more likely that further empirical studies will reveal the core of procedural justice, which may have a universal character. Three factors: voice, respect and neutrality, seem to have this kind of character.

The interrelations between the dimensions of procedural justice revealed in the Polish study shows that it should be expected that procedural justice is a phenomenon comprising interdependent components. Consequently, in order to accurately define the phenomenon of procedural justice, it is necessary to consider its multiple aspects simultaneously. Building the subjective evaluation of the fairness of court proceedings is the outcome of a complex network of interactions taking place at several essentially interrelated levels. Perhaps it is precisely due to this coherence of its various dimensions that procedural justice is, ultimately, such an important aspect of a person's functioning in institutional structures.

The revised PJS also turned out to have acceptable criterion validity: its scores were strongly correlated with well-being and, less strongly, with satisfaction with life. The last of these results highlights the distinct character of the analyzed construct and, perhaps, its essential stability, as opposed to well-being as understood in both the eudaimonic and hedonistic paradigms.

The elaborate analysis of PJS reliability, including not only the standard estimators of this dimension of measure goodness, showed that the reliability coefficients of three out of the five subscales: Voice, Neutrality, and Respect, as well as overall score reliability, were high or acceptable. The values of most reliability 
estimators for two subscales: Understanding and Influence, were unacceptable or bordered on acceptable. This means that scores on these subscales should not be taken into account in individual assessment. In this respect, work on the measure has not been completed: the PJS requires further research, which may confirm or falsify the internal consistency of the subscales in question.

It is worth noting that also the results of intergroup analyses confirm the assumptions of the model of procedural justice. The social expectation of procedural justice is universal; this justice is expected to the same degree by women and men, across education levels and ages. The demographic variables included in the present study turned out not to have a differentiating character.

The revised version of the PJS presented in this article clears up most of the doubts that a psychologist might have about the version of the scale adapted by Burdziej (2018). It should be noted that the first, highly valuable version was prepared by sociologists and was used in studies conducted in accordance with a methodology different than psychological. The version of the PJS validated in the present study concerns exclusively the area of behaviors identifiable with the measured construct and does not include items operationalizing formal issues, least of all organizational and infrastructural ones. This means the presented questionnaire distinctly operationalizes an important theoretical construct (Hornowska, 2006). The PJS has been made uniform in terms of test item formatboth the stimulus and the scale on which the respondent indicates his or her reaction. Some of the subscales have been expanded to include more behavioral indicators, the assumption being that the more indicators of various kinds are taken into account, the more accurate conclusions it is possible to reach concerning a given psychological characteristic.

In summary, it is legitimate to say that the revised PJS can successfully be used in research, with two reservations. The first reservation is that some of the subscales require further validation, particularly in respect of reliability. The other one is that further studies should make it possible to answer the question of whether there are dimensions of procedural justice in the population for which the measure has been adapted that have not been considered before at the theoretical level but constitute a significant component of the analyzed phenomenon. It is worth stressing, as Jonkisz (1998) does, that no model - not even a very well-fitted one-is the only model distributing a phenomenon. In the process of constructing, revising, and adapting psychological measures, the construction of alternative models is an important and valuable practice. Further research will undoubtedly test whether or not the proposed structure of procedural justice is 
universal and if it explains the phenomenon adequately. The results supplement the findings of previous studies on the theory of procedural justice.

\section{REFERENCES}

Adams, J. S. (1963). Towards an understanding of inequity. Journal of Abnormal and Social Psychology, 67, 422-436.

Antonovsky, A. (2005). Rozwiktanie tajemnicy zdrowia [Unraveling the mystery of health]. LQ.

Aranowska, E. (2005). Pomiar ilościowy w psychologii [Quantitative measurement in psychology]. Scholar.

Aranowska, E., \& Rytel, J. (2012). Struktura czynnikowa kwestionariusza agresji Bussa i Perry'ego (BPQA) w polskiej adaptacji [The factor structure of the Polish adaptation of the Buss-Perry Aggression Questionnaire (BPAQ)]. Studia Psychologica, 2, 135-151.

Aranowska, E., \& Rytel, J. (2013). Kontrowersje wokół rzetelności jako pojęcia psychometrycznego [Controversies surrounding reliability as a psychometric concept]. Przeglad Psychologiczny, 56(1), 29-43.

Bierhoff, H. W., Buck, E., \& Klein, R. (1986). Social context and perceived justice. In H. W. Bierhoff, R. L. Cohen, \& J. Greenberg (Eds.), Justice in social relations (pp. 165-186). Plenum Press.

Blader, S. L., \& Tyler, T. R. (2003). A four-component model of procedural justice: Defining the meaning of a "fair" process. Personality and Social Psychology Bulletin, 29(6), 747-758.

Blader, S. L., \& Tyler, T. R. (2009). Testing and Extending the Group Engagement Model: Linkages Between Social Identity, Procedural Justice, Economic Outcomes, and Extrarole Behavior. The Journal of Applied Psychology, 94(2), 445-464.

Boda, Z., \& Medve-Bálint, G. (2014). Does institutional trust in East Central Europe differ from Western Europe? European Quarterly of Political Attitudes and Mentalities, 3(2), 1-17.

Burdziej, S. (2018). Sprawiedliwość i prawomocność [Justice and legitimacy]. Wydawnictwo Naukowe UMK.

Burdziej, S., Guzik, K., \& Pilitowski, B. (2018). Fairness at trial: The impact of procedural justice and other experiential factors on criminal defendants' perceptions of court legitimacy in Poland. Law \& Social Inquiry, 1-32.

Calton, J., \& Cattaneo, L. B. (2014). The effects of procedural and distributive justice on intimate partner violence victims' mental health and likelihood of future help seeking. American Journal of Orthopsychiatry, 84, 329-340.

Cattaneo, L. B., \& Goodman, L. A. (2010). Through the lens of therapeutic jurisprudence: The relationship between empowerment in the court system and well-being for intimate partner violence victims. Journal of Interpersonal Violence, 25(3), 481-502.

Cieciuch, J., \& Karaś, D. (2017). Polska adaptacja kwestionariusza dobrostanu (Psychological Well-Being Scales) Caroll Ryff [Polish adaptation of Carol Ryff's Psychological Well-Being Scales]. Roczniki Psychologiczne, 4(20), 815-835.

Cohn, E. S., White, S. O., \& Sanders, J. (2000). Distributive and procedural justice in seven nations. Law and Human Behavior, 24(5), 553-579. 
Colquitt, J. A., Conlon, D. E., Wesson, M. J., Porter, C. O., \& Ng, K. Y. (2001). Justice at the millennium: A meta-analysis of 25 years of procedural justice research. Journal of Applied Psychology, 86, 425-445.

Czapiński, J. (Ed.) (2004). Psychologia pozytywna [Positive psychology]. PWN.

Daniel, K. (2007). Kryzys społecznego zaufania do sądów [The crisis of public trust in courts]. Studia Socjologiczne, 2, 61-82.

Dickerson, S. S., \& Kemeny, M. E. (2004). Acute stressors and cortisol responses: A theoretical integration and synthesis of laboratory research. Psychological Bulletin, 130(3), 355-391.

Diener, E., Oishi, S., \& Lucas, R. E. (2003). Personality, culture, and subjective well-being: Emotional and cognitive evaluations of life. Annual Review of Psychology, 54(1), 403-425.

Greenberg, J. (1986). Determinants of perceived fairness of performance evaluations. Journal of Applied Psychology, 71, 340-342.

Jałoszewski, M. (2012). Sędzia idealny [The perfect judge]. Na wokandzie, 1(11), 17-18.

Jonkisz, A. (1998). Ciagłość teoretycznych wytworów nauki. Ujęcie strukturalne [The continuity of theoretical products of science: A structural perspective]. WUMSC.

Konarski, R. (2016). Modele równań strukturalnych [Stuctural equation models]. PWN.

Kurczewski, J. (1982). Spór i sądy [Litigation and courts]. Wydawnictwo UW.

Kurczewski, J., \& Fuszara, M. (Eds.). (2004). Polskie sądy i spory [Polish courts and litigations]. Ośrodek Badań Społecznych ISNS UW.

Lind, E. A., \& Tyler, T. R. (1988). The social psychology of procedural justice. Springer Science and Business Media.

Murphy, K., Tyler, T. R., \& Curtis, A. (2009). Nurturing regulatory compliance: Is procedural justice effective when people question the legitimacy of the law? Regulation \& Governance, $3,1-26$.

Niesiobędzka, M. (2009). Relacje podatnik - państwo jako predyktory moralności podatkowej [Taxpayer-state relations as predictors of tax morality]. Psychologia Spoleczna, 3(11), 123-132.

Pavot, W., Diener, E., \& Suh, E. (1998). The Temporal Satisfaction With Life Scale. Journal of Personality Assessment, 70, 340-354.

Podgórecki, A. (1971). Zarys socjologi iprawa [An outline of the sociology of law]. PWN.

Prusiński, T. (2018). Sprawiedliwość instytucjonalna a zdrowia psychiczne stron postępowań sądowych. Wzmocnienie czy obniżenie jednostkowego dobrostanu? [Institutional justice and the mental health of parties to court proceedings. Enhancement or deterioration of individual well-being?]. Polskie Forum Psychologiczne, 2(23), 446-468.

Ptacek, J. (1999). Battered women in the courtroom: The power of judicial responses. Northeastern University Press.

Rousseau, V., Salek, S., Aube, C., \& Morin, E. M. (2009). Distributive justice, procedural justice, and psychological distress: The moderating effect of coworker support and work autonomy. Journal of Occupational Health Psychology, 14, 305-317.

Ryff, C. D. (1989). Happiness is everything, or is it? Explorations on the meaning of psychological well-being. Journal of Personality and Social Psychology, 57, 1069-1081.

Skąpska, G., \& Bryda, G. (2013). Apolityczność czy sprawiedliwość proceduralna? Zaufanie do sądowego wymiaru sprawiedliwości na tle innych instytucji publicznych w Polsce [Apoliticality or procedural justice? Trust in the court judiciary compared to other public institutions in Poland]. Studia Socjologiczne, 1(208), 77-94. 
Szymańska, A. (2016). Założenia formalne modeli weryfikowanych przy pomocy układów równań strukturalnych [Formal assumptions of the structural equation models]. Studia Psychologica, 1(16), 5-25.

Thibaut, J., \& Walker, L. (1975). Procedural justice: A psychological analysis. Erlbaum.

Tomkins, A., \& Applequist, K. (2008). Constructs of justice: Beyond civil litigation. In B. H. Bornstein, R. L. Wiener, R. Schopp, \& S. L. Willborn (Eds.), Civil juries and civil justice (pp. 257-272). Springer.

Törnblom, K., \& Vermunt, R. (Eds.) (2016). Distributive and procedural justice: Research and social applications. Routledge.

Tyler, T. R. (1984). The role of perceived injustice in defendant's evaluations of their courtroom experience. Law \& Society Review, 18, 51-74.

Tyler, T. R. (2007). Procedural justice and the courts. Court Review, 44(1/2), 26-31.

Tyler, T. R. (2010). Social justice: Outcome and procedure. International Journal of Psychology, $35(2), 117-125$.

Tyler, T. R., Degoey, P., \& Smith, H. (1996). Understanding why the justice of group procedures matters: A test of the psychological dynamics of the group-value model. Journal of Personality and Social Psychology, 70(5), 913-930.

Tyler, T. R, \& Huo, Y. J. (2002). Trust in the law: Encouraging public cooperation with the police and courts through. Russell Sage Foundation.

Tyler, T. R, \& Rasinski, K. (1991). Procedural justice, institutional legitimacy, and the acceptance of unpopular U.S. Supreme Court decisions: A reply to Gibson. Law \& Society Review, 25(3), 621-630.

Vermunt, R., Van der Kloot, W. A., \& Van der Meer, J. (1993). The effects of procedural and interactional criteria on procedural fairness judgments. Social Justice Research, 6(2), 183-195. 


\section{Appendix 1 \\ Procedural Justice Scale \\ Polish adaptation by Burdziej \& Pilitowski, 2014 \\ Revised by Prusiński, 2018 \\ Instruction}

The statements below refer to your experience in the courtroom. Indicate the extent to which you agree or disagree with each statement. For each item, choose one of the following five answers:

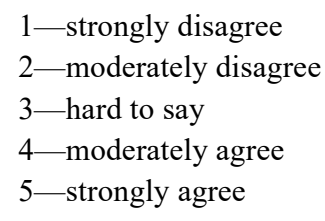

Circle only one answer next to each item. Do not omit any of them.

1. Sędzia wysłuchał(a) mojego stanowiska z należytą uwagą.

2. Miałem(am) poczucie, że nie rozumiem, co dzieje się na sali sądowej.

3. Sędzia był(a) do mnie uprzedzony(a).

4. Sędzia traktował(a) mnie w uprzejmy sposób.

5. Nie miałem poczucia wpływu na przebieg posiedzenia.

6. Podczas posiedzenia/rozprawy mogłem(am) w satysfakcjonujący sposób przedstawić swoje dowody.

7. Miałem(am) poczucie, że rozumiem w pełni język, którym posługiwano się na sali sądowej.

8. Sędzia patrzył(a) mi w oczy, gdy się komunikowaliśmy.

9. Sędzia przedstawił(a) plan posiedzenia.

10. Mam poczucie, że postępowanie sądowe jest prowadzone przez sędziego w rzetelny sposób.*

11. Sędzia w zrozumiały sposób wyjaśniał(a) kwestie proceduralne i używane przez siebie terminy.

12. Sędzia otrzymał(a) wystarczającą ilość informacji, by podjąć właściwą decyzję.

13. Sędzia nie wziął(ęła) pod uwagę przedstawionych przeze mnie dowodów.

14. Sędzia w równym stopniu wziął(ęła) pod uwagę argumenty obu stron.

15. Sędzia upewniał(a) się, że rozumiem, co dzieje się na sali sądowej.

16. Sędzia zwracał(a) się do mnie nie używając zwrotów grzecznościowych.

17. Miałem poczucie wpływu na decyzje sędziego.

18. Stworzono mi możliwość przedstawienia własnego stanowiska.*

19. Mam poczucie, że sędzia potraktował(a) mnie z godnością.*

20. Mam poczucie, że nie zostałem wysłuchany.*

21. Sędzia podczas postępowania zachowywał(a) neutralność.*

22. To co działo się na sali sądowej było dla mnie niejasne.* 